\title{
ДОСВІД ВПРОВАДЖЕННЯ МЕТОДУ НАВЧАННЯ НА КАФЕДРІ ПАТОЛОГІЧНОЇ АНАТОМІЇ, ОСНОВАНОГО НА ПРИНЦИПІ РОЗБОРУ КЛІНІЧНИХ ВИПАДКІВ (САSE-ВASED LEARNING). ЧАСТИНА 1: ОПИС МЕТОДУ
}

\author{
O. O. Bondarenko, N. S. Petruk, I. S. Shponka \\ SE “Dnipropetrovsk Medical Academy of Health Ministry of Ukraine”, Dnipro \\ CASE-BASED LEARNING: TRIAL EXPERIENCE ON THE \\ PATHOLOGICAL ANATOMY DEPARTMENT. PART I: METHOD \\ DESCRIPTION
}

\begin{abstract}
Мета роботи. Стаття присвячена опису методу викладання, основаного на принципі розбору клінічних випадків, що проводилося на кафедрі патологічної анатомії Д3 “ДМА МОЗ України” протягом 2016-2017 академічного року. Метою даного впровадження була модернізація методології навчання, оптимізація та стандартизація навчального процесу. Досліджуваний метод викладання був впроваджений на практичних заняттях серед груп англомовних студентів медичного факультету третього курсу.

Основна частина. Для проведення занять за даною методикою ми відбирали й адаптували клінічні випадки з відкритих баз даних USMLE, MCCEE та інших джерел, які найбільш широко й актуально охоплювали відповідну тему заняття. До обраного клінічного випадку будувалося завдання: тест з множинним вибором, тестові зображення мікро- та макропрепаратів, опис обраних макро- та мікропрепаратів і проблемні запитання, які залучали аналітичні та синтетичні здібності мислення і найширше освітлювали теоретичну базу захворювань та станів, згаданих у даному випадку.

Висновки. Показано, що викладання, основане на вивченні клінічних випадків, може бути конкурентоспроможною альтернативою традиційній методиці викладання патологічної анатомії, оскільки беззаперечно покращує логічні навички студентів, стимулює клінічне мислення, сприяє розвитку автономності, розвиває комунікативні навички, приводить до кращого збереження знань та стимулює мотивацію студента до навчання.
\end{abstract}

Ключові слова: медична освіта; патоморфологія; case-based learning; інтерактивне навчання.

The aim of the study - the trial of case-based learning that was performed on the Pathological Anatomy Department of SE “Dnipropetrovsk Medical Academy of Health Ministry of Ukraine” during 2016-2017 academic year is described in the article. The objective of this trial was the modernizing teaching methodology, optimizing and standardizing the learning process. The approbation of this methodology was performed on the practical classes among the third-year English-speaking students.

The main body. For the teaching purposes by this method clinical cases from public databases USMLE, MCCEE and other sources that were most relevant to the corresponded topics and widely covered them were selected and adapted. The tasks were structured according to the chosen cases and included: multiple choice questions, multiple choice questions with gross images and micrographs, descriptive task about the selected micro and gross images, and, finally, challenging questions that involved analytical and synthetic thinking ability and provided extensive coverage of theoretical basis for diseases and conditions referred to in this case.

Conclusion. It was demonstrated that case-based learning method can be definitely competitive studying technique as an alternative "method-of-choice" due to its efficacy in terms of amelioration of student's logical skills, clinical thinking stimulation, and communicative skills development. Thus, it advantages in autonomy development and motivates the students to study.

Key words: medical teaching; pathomorphology; case-based learning; interactive learning.

Вступ. Патологічна анатомія - навчальна клінічна дисципліна, що займає одне з ключових місць у процесі підготовки майбутнього лікаря. Вивчення морфологічної основи типових загальнопатологічних процесів та нозологічних форм хвороб проводиться нерозривно з аналізом клінічної картини

(C) О. О. Бондаренко, Н. С. Петрук, І. С. Шпонька захворювання. Окрім цього, патоморфологія вивчає принципи формулювання діагнозу, формуючи у студента відповідні навички [1, 2].

Сучасна система освіти змінюється та, відповідно до засад Болонського процесу, вимагає зсуву акцентів у бік студента, як активного учасника педагогічного процесу, здатного самостійно отримувати та 
осмислювати теоретичний матеріал і застосовувати його у своїй майбутній професійній діяльності. Звичайно, це вимагає використання різноманітних інноваційних прогресивних методів навчання, $\mathrm{y}$ тому числі із залученням зручних інтерактивних інструментів обміну інформацією та консультацій у системі “викладач - студент” [3, 4].

В аспекті викладання такої дисципліни, як патоморфологія, необхідно зазначити, що дана наука лежить на зламі теоретичної та клінічної медицини та потребує застосування методів, що інтегрують ці напрями. Навчання, орієнтоване на розборі випадків із практики (case-based learning, CBL), є одним із таких підходів і може зробити педагогічний процес більш ефективним та цікавим. За допомогою даного методу викладання студент отримує змогу розвинути навички аналітичного клінічного мислення, критичного судження та взяти участь в обговоренні комплексних ситуативних задач із практичної діяльності [5].

Мета роботи. Стаття присвячена опису методу викладання, основаного на принципі розбору клінічних випадків, що проводилося на кафедрі патологічної анатомії ДЗ “ДМА МОЗ України” протягом 2016-2017 академічного року. Метою даного впровадження була модернізація методології навчання, оптимізація та стандартизація навчального процесу. Досліджуваний метод викладання був впроваджений на практичних заняттях серед груп англомовних студентів медичного факультету третього курсу у 2016-2017 н. р.

Основна частина. Підготовка матеріалів до практичного заняття. Для запровадження методики клінічно-орієнтованих випадків ми використовували певний алгоритм методологічної підготовки матеріалів до занять, що мало на меті створення найбільш релевантних клінічних завдань, які б, на нашу думку, відповідали меті практичного заняття з певної теми. Цей алгоритм, по-перше, включав в себе завчасний пошук, відбір і адаптацію клінічних випадків відповідно до програми навчання, які найбільш широко й актуально охоплювали відповідну тему заняття. 3 цією метою ми досліджували доступні бази даних USMLE Step 1, MCCEE та інші джерела [6-8], які містили в собі не тільки тестові завдання з клінічними віньєтками (MCQ, “multiple choice question”), а й пояснення з обгрунтуванням вибору правильної відповіді, що допомагало надалі послідовно побудувати структуру завдання і сформувати проблемні запитання. Критеріями відбору слугували відповідність випадків до існуючої програми навчання, клінічна актуальність та рівень підготовки студентів. Окрім того, ми обирали тестові завдання $з$ еквівалентним рівнем складності. Таким чином, з одного боку, ми не дублювали завдання 3 існуючої бази даних тестів “Крок-1”, з іншого - додавали можливості більш глибоко розв’язати певний тест, сфокусувавши студента на стратегії пошуку правильної відповіді, обгрунтовуючи як її вибір, так і виключення дистракторів.

Обраний клінічний випадок (віньєтка) слугував віссю, вздовж якої будувалося усе завдання. Окрім тесту з множинним вибором, до даного випадку підбиралися або створювалися зображення мікро- та макропрепаратів, які, з одного боку, самі по собі виконували функцію візуального тестування, де студент серед дистракторів обирав мікро- та макрозображення, найбільш відповідне даному випадку. 3 іншого боку, обрані зображення використовувались для виконання наступних завдань 3 опису макро- та мікропрепаратів, але, на відміну від класичної методики проведення практичних занять, де всі студенти групи описують та замальовують однакові препарати, виконання цього завдання було індивідуалізоване - кожен студент описував тільки свій обраний препарат.

До цього ж клінічного випадку створювались проблемні запитання, які мали більший рівень складності, залучали аналітичні та синтетичні здібності мислення і найширше освітлювали теоретичну базу захворювань та станів, згаданих у даному випадку.

Підготовлені зображення мікро- і макроскопічних препаратів попередньо публікувались на офіційному веб-сайті Дніпропетровської медичної академії та в соціальних мережах для підготовки студентів до наступного заняття. При цьому для більшої зручності до зображень готувалися підписи, перелік можливих питань, рекомендованих літературних джерел та корисних посилань.

Останнім кроком підготовчого етапу було макетування та виготовлення комплектів навчальних завдань (як правило, 10 варіантів) у прийнятному для роботи дизайні.

Існуюча академічна тривалість заняття (1 год 20 хв) дозволяла структурувати його за наступним планом:

1. Аналіз результатів попереднього заняття і робота над помилками (20 хв). Таким чином, студенти повторювали та закріпляли минулу тему.

2. Розбір поточної теми: слайд-семінар (опціонально - робота з мікроскопами) і дискусія (30 хв). Так, використовуючи набір раніше опублікованих макро- та мікрозображень або еквівалентних їм мі- 
кро- та макропрепаратів, студенти разом із викладачем востаннє перед відповіддю на індивідуальне завдання робили ревізію поточної теми. При цьому, зазвичай, викладач вже міг скласти певне враження про рівень підготовки студента, а останній, у свою чергу, міг отримати додаткові бали за усну відповідь, беручи участь в обговоренні.

3. Письмове виконання індивідуального завдання (30хв). Використовуючи засоби інформаційної безпеки (контроль за мобільними пристроями із забезпеченням “електронної тиші”, попередження використання підручників, конспектів тощо), викладач забезпечував проведення остаточного письмового контролю засвоєння отриманих знань, вмінь та навичок.

Після завершення відведеного на завдання часу робочі зошити з письмовими відповідями і листи з завданнями збирали і перевіряли впродовж поточного робочого тижня.

Індивідуальне письмове завдання складалося 3 таких компонентів (рис. 1):

1. Умова, що описувала певний клінічний випадок. За необхідністю, завдання доповнювалося довідковими матеріалами стосовно нормальних значень фізіологічних параметрів організму або певних функціональних та лабораторних тестів.

2. Тестове питання з однією правильною відповіддю, за яку нараховувалось 0,5 бала.

3. Ілюстративні тестові матеріали (рис. 2). У додатку до письмового завдання містилося по чотири кольорових мікро- та макрозображення, з яких треба було обрати по одній правильній відповіді, кожна з яких оцінювалась по 0,25 бала.

\section{Lesson 2. CELL INJURY. INTRACELLULAR ACCUMULATIONS. Case \#1}

\begin{tabular}{|c|c|c|}
\hline \multicolumn{3}{|c|}{$\begin{array}{l}\text { A } 48 \text {-year-old man has a history of chronic alcohol abuse. He is still able to perform work at his job } \\
\text { He has had no major illnesses. On physical examination, there are no significant findings } \\
\text { Laboratory studies show a serum albumin of } 4.1 \mathrm{~g} / \mathrm{dL} \text {. ALT } 30 \text { UR. AST } 33 \text { UR, and total bilirubir } \\
1.1 \mathrm{mg} / \mathrm{dL} \text {. }\end{array}$} \\
\hline 1. & $\begin{array}{l}\text { Answer the test. Which of the following microscopic findings in his } \\
\text { liver is most likely to be prosent? } \\
\text { A Cholestasis. } \\
\text { B Fatty change. } \\
\text { C Hemochromatosis. } \\
\text { D Hypertrophy of smooth endoplasmic reticulum. } \\
\text { E Coagulative necrosis. }\end{array}$ & 0.5 point \\
\hline 2. & $\begin{array}{l}\text { From the given images choose the most relevant one to the } \\
\text { described condition. }\end{array}$ & 0.5 points \\
\hline 3. & $\begin{array}{l}\text { Describe and schematically indicate the essential histological } \\
\text { findings of chosen image according to the standard algorithm. }\end{array}$ & 1.5 points \\
\hline 4. & $\begin{array}{l}\text { Perform the examination of chosen gross specimen according } \\
\text { to the standard algorithm. Indicate all possible causes and } \\
\text { outcomes of this condition. }\end{array}$ & 1.5 points \\
\hline 5. & $\begin{array}{l}\text { Answer the questions } \\
\text { A) What is the molecular pathway of intracellular accumulation in this } \\
\text { case? } \\
\text { B) What kind of histological staining can prove the presence of the } \\
\text { deposited substance? How will the results look like? } \\
\text { C) Do you know the other type of intracellular accumulation that may } \\
\text { occur in hepatocytes due to the same etiology? What is the specific } \\
\text { term for such kind of deposit? }\end{array}$ & 3 points \\
\hline
\end{tabular}

Total Score: 7 points

Suggested Runtime: $30^{\prime}$

WARNINGI All test books, draft booklets, and student answers are secured materials! Any reproduction of the teaching materials is strictly forbidden!

6

Any infringement of this restriction will lead to the personal or collective penalties, including the monetary fines for restoration of compromised materials ("Internal Regulations of DMA" VIII, $8.6, \S \S 4,8)$

Рис. 1. Приклад індивідуального письмового завдання за темою “Ушкодження клітини. Внутрішньоклітинне накопичення” (традиційна назва: “Паренхіматозні дистрофії”). До складу завдання входять: 1 - умова; 2 - тестове питання; 3 - опис обраного мікропрепарату; 4 - опис обраного макропрепарату із зазначенням діагнозу, причин і наслідків; 5 - вирішення проблемних і теоретичних питань; 6 - попередження про дотримання інформаційної безпеки. 
Lesson 2. CELL INJURY. INTRACELLULAR ACCUMULATIONS. Case \#1
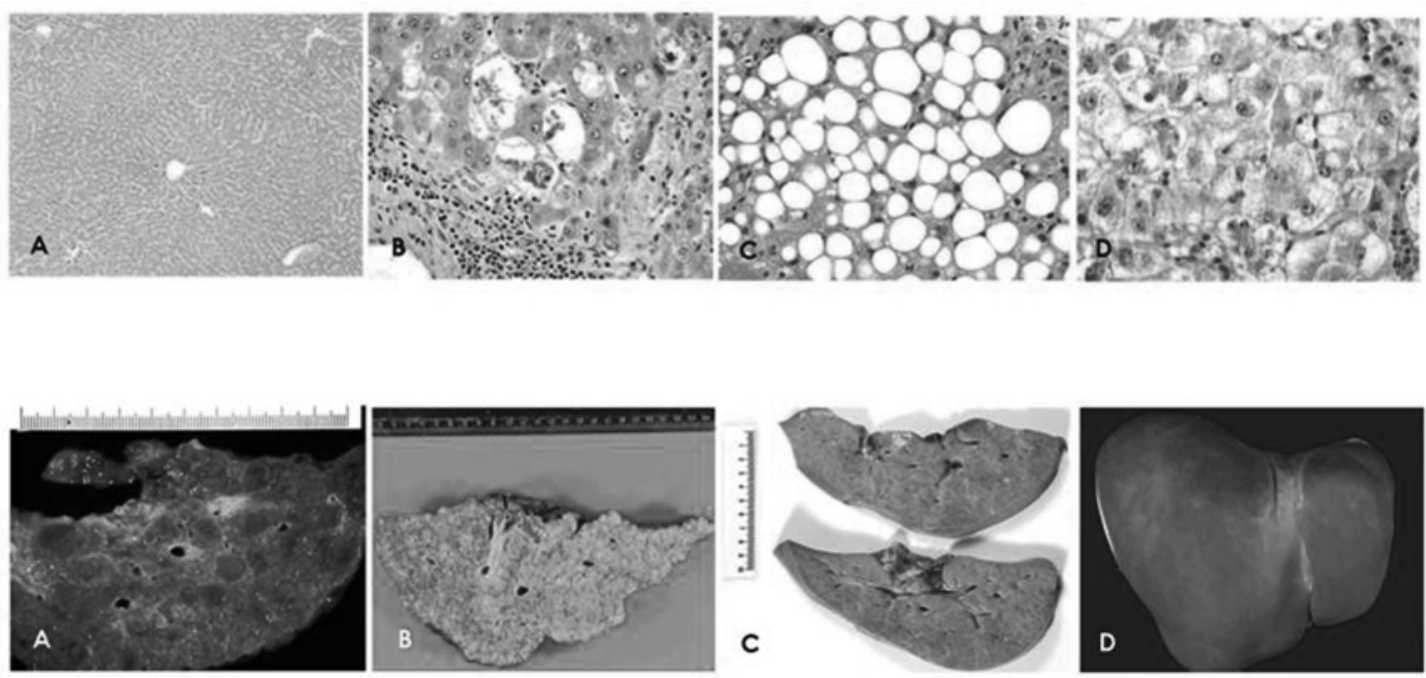

Рис. 2. Додаток до письмового завдання з тестами на основі мікро- та макрозображень.

4. Опис обраних препаратів із подальшим встановленням діагнозу й зазначенням можливих причин та ускладнень поточного стану, що надавали студенту загалом 3 бали (по 1,5 бала за кожний компонент).

5. Вирішення проблемних і теоретичних питань. За вичерпну відповідь на кожне з трьох питань студент отримував по 1 балу.

Отже, за повністю правильну відповідь студент отримував 7 балів. Відповідно до традиційної оцінки нараховані бали конвертувались таким чином: 0-2,4 - “незадовільно”; 2,5-4,4 - “задовільно”; 4,5-6,0 - “добре”; 6,1-7 - “відмінно”.

Відповідно до форми індивідуальних завдань були створені робочі зошити, в яких студенти залишали свої відповіді. Окрім того, робочий зошит використовувався як довідник, де міститься інформація про алгоритми опису мікро- та макропрепаратів, методи гістологічного забарвлення та показники лабораторних тестів.

У нашій методиці ми застосували зовнішні віртуальні носії та обмінники даних, а також соціальні мережі як для самостійної підготовки студентів, так і проведення віртуальних консультацій, дискусій

\section{Список літератури}

1. Вернигородський С. В. Проблемні питання викладання патоморфології та секційно-біопсійного курсу в рамках реалізації Національної стратегії побудови нової системи охорони здоров’я / С. В. Вернигородський, П. С. Жученко // Проблеми та перспективи вищої медичної школи у розробці та реалізації Національної стратегії тощо. Наприклад, перед початком наступного циклу спеціальної або загальної патології ілюстративний матеріал розміщувався у віртуальній теці або у спеціально створеній групі у соціальній мережі, де студентам відкривався доступ до дискусії навколо наступного заняття, яка була керована викладачем. Поруч із цим проводились опитування студентів 3 метою контролю якості засвоювання викладеного матеріалу та зворотного зв'язку.

Слід зазначити підвищення рівня мотивації студентів при підготовці до занять, що проявлялось у вигляді дискусій навколо поточної теми, які можна було спостерігати і координувати.

Висновки. Таким чином, з великою часткою упевненості можна стверджувати, що викладання, основане на вивченні клінічних випадків, на наш погляд, може бути конкурентоспроможною альтернативою традиційній методиці викладання патологічної анатомії, оскільки беззаперечно покращує логічні навички студентів, стимулює клінічне мислення, сприяє розвитку автономності, розвиває комунікативні навички, приводить до кращого збереження знань та стимулює мотивацію студента до навчання.

побудови нової системи охорони здоров’я в Україні на період 2015-2025 рр : зб. матеріалів навч.-метод. конф., 25 берез. 2015 р. - Вінниця, 2015. - С. 21-22.

2. Marshall R. Teaching and learning pathology: a critical review of the English literature / R. Marshall, N. Cartwright, K. Mattick // Med Educ. - 2004. - Vol. 38, № 3. - P. 302,13. 
3. Buch A. C. Interactive teaching: Understanding perspectives of II MBBS students in Pathology / A. C. Buch, S. S. Chandanwale, S.A. Bamnikar// Med. J. D.Y. Patil. Univ.2014. - Vol. 7. - P. 693-5.

4. Stahl S. M. Best Practices in Medical Teaching / S. M. Stahl, R. L. Davis. - NY : Cambridge University Press, 2011. - 178 p.

5. Undergraduate medical students' feedback and perceptions on teaching learning methodology in Pathology at Government Medical College / S. S. S. Quadri, S. Shya- mala, S. Mahesh, B. Bheeshma // IAIM. - 2016. - Vol. 3, № 7. - P. 28-35.

6. Klatt E. Robbins and Cotran Review of Pathology / E. Klatt, V. Kumar. - 4th edition. - Saunders, 2014. - 504 p.

7. Le T. First Aid for the USMLE Step 1, 2016 / T. Le, V. Bhushan. - McGraw Hill Professional, 2015. - 760 p.

8. Chowdhury J. Essentials for the Canadian Medical Licensing Exam, Part 1 / J. Chowdhury, A. I. Cozma, J. H. Chowdhur. - 2nd edition. - Wolters Kluwer, 2016. 784 p.

3. Buch, A.C., Chandanwale, S.S., \& Bamnikar, S.A. (2014). Interactive teaching: Understanding perspectives of II MBBS students in Pathology. Medical Journal of Dr. DY Patil University, 7(6), 693.

4. Stahl, S.M., \& Davis, R.L. (2011). Best practices in medical teaching. Cambridge University Press.

5. Quadri, S.S.S., Srujana, S., Mahesh, S., \& Bheeshma, B. (2016). Undergraduate medical students' feedback and perceptions on teaching learning methodology in Pathology at Government Medical College. IAIM, 3(7), 28-35.

6. Klatt, E.C., \& Kumar, V. (2014). Robbins and Cotran review of pathology. Elsevier Health Sciences.

7. Le, T., Bhushan, V., Tolles, J., \& Hofmann, J. (2010). First aid for the USMLE step 1 2013. McGraw-Hill Medical.

8. Chowdhury, J., Cozma, A.I., \& Chowdhur, J.H. (2016). Essentials for the Canadian Medical Licensing Exam, Part 1. 2nd ed. Wolters Kluwer.

2. Marshall, R., Cartwright, N., \& Mattick, K. (2004).

Teaching and learning pathology: a critical review of the English literature. Medical education, 38(3), 302-313. 